\title{
Effect of Bangun-bangun Leaves, Coleus amboinicus, $L$ as a Feed Additive on the Broiler Performance
}

\author{
N Fati' ${ }^{1}$, R Siregar ${ }^{2}$, S Sujatmiko ${ }^{3}$ \\ Department of Food Crop Cultivation Agricultural, State Agricultural Polytechnic of \\ Payakumbuh, 26271 Tanjung Pati, Payakumbuh, Indonesia ${ }^{1,2,3}$ \\ \{nelzifati@.gmail.com $\left.{ }^{1}\right\}$
}

\begin{abstract}
The use of synthetic antibiotics in feeds that act as growth promoters or AGP (antibiotic growth hormone) has long been used freely, as a result of which is the residue of the antibiotic is still present in livestock products. So came the feed additives derived from medicinal plants. As for feed additives that have been used are salam leaves and binahong leaves. Besides, the bangun-bangun leaves have the potential as antibiotic-antioxidant replacement synthetic antibiotics and no researchers who use it in ration poultry. This study aims to test the influence of addition of extract leaves bangun-bangun in rations to population colonies Escherichia coli, total colony bacteria an aerobic and broiler performance at the age of 7 days, 160 tails broiler unsexing grouped eight the treatment group as follows: 1) control positive 2) control negative, 3) broiler given $2 \%$ simplicia bangun-bangun leaves in rations, 4) broiler given 4\% Simplicia bangun-bangun leaves in rations, 5) broiler given rations containing extract $96 \%$ ethanol bangunbangun leaves as much as $2 \mathrm{~g} / \mathrm{kg}, 6$ ) broiler given rations containing extract $96 \%$ ethanol bangun-bangun leaves as much as $4 \mathrm{~g} / \mathrm{kg}$, 7) broiler given rations containing extract underwater leaves bangun-bangun $2 \mathrm{~g} / \mathrm{kg}$ rations 8) broiler given rations containing extract underwater leaves bangun-bangun $4 \mathrm{~g} / \mathrm{kg}$ rations. The variable measured is population bacteria Escherichia coli, total colony bacteria an aerobic, weight gain, food rations, and conversion rations. Supplementation extract bangun-bangun leaves had significant effect $(\mathrm{P}<0,01)$ on the decrease of the bacterium Escherichia coli, and a number of bacteria, and extract significantly $(\mathrm{P}>0,05)$ to weight on gain, ration consumption and ration conversion. Conclusion of extract supplementation $96 \%$ bangun-bangun leaves ethanol $4 \mathrm{~g} / \mathrm{kg}$ is best in lowering the population of Escherichia coli bacteria, and supplementation of leaves bangun-bangun extract can be tolerated to weight gain, consumption and conversion of rations.
\end{abstract}

Keywords: Extract, bangun-bangun leaves, weight gain, antibiotic, simplicia

\section{Introduction}

The provision of natural food, safe, and quality becomes a big challenge for practitioners, especially in the field of food. World trends lead to secure food demands, one of which is free of antibiotics for livestock products. One solution is to reduce the use of antibiotics that act as therapeutic antibiotics and AGP (antibiotic growth promoter). The Indonesian government's 
policy on food security is to produce enough livestock products (meat, eggs, and milk) in affordable prices and have good quality standards.

The use of antibiotic compounds in rations has been a major topic of discussion for scientists, sometimes a fierce debate resulting from adverse effects on consumers arising from the consumption of livestock products containing antibiotics in the animal feed, resulting from residuals left on eggs, milk or meat. The prohibition of the use of antibiotics in the ration is actually not a new thing for some European countries. Sweden in 1986, Denmark 1995 and Switzerland in 1999 have limited the use of additives in animal feed. The European Union community has established January 1, 2006 (based on regulation No. 1831/2003) which is a milestone in the destruction of various antibiotic usages, which for the past decades is a substance often used by farmers in different parts of the world. It cannot be denied that since the use of antibiotics in animal feed as a growth promoter compound, there has been an increase in income from farmers due to the ability of these compounds that can convert nutrients in the feed efficiently and effectively. The discovery of microbial resistance in residues in livestock products due to antibiotics has inspired the search for alternative products to replace antibiotics. Microbial resistance can be transferred from livestock to the human body, through direct human contact with livestock or indirectly through the consumption of animal products (including marine animals) and preserved antibiotic food ingredients. In the human body, bacteria will colonize and can lead to various health problems, can even cause death. The use of synthetic antibiotics in feeds that act as growth promoters or AGP (antibiotic growth promoter) has long been used freely, as a result of which is the residue of the antibiotic is still present in livestock products. So came the feed additives derived from medicinal plants. As for feed additives that have been used are katuk leaf [1], salam leaves [2], beluntas leaves [3], binahong leaves [4]. One plant that can also be used as a medicinal plant is bangun-bangun leaves.

Bangun-bangun leaves (Coleus amboinicus, L) have long been exploited by the Batak people who develop and use it. According to the Batak people who consume bangun-bangun leaves this can play a role in maintaining and improving the health of the body, in addition, it can also increase the amount of breastfeeding breast milk. Bangun-bangun leaves also have various properties such as overcoming fever, influenza, cough, constipation, inflammation, bloating, headache, allergies, diarrhea and increase milk. Bangun-bangun leaf plants are a soft-stemmed plant species, not woody or contain only very little wood tissue, so that at the end of the growing period of death to the base without any part of the stems left on the ground. Bangun-bangun plant (Coleus ambonicus), is a kind of plant that can live only one year and can also be an annual crop [5], usually grows wild either in the yard, the garden even up the mountain area, with a height of $1000 \mathrm{~m}$ or $1100 \mathrm{~m}$ above sea level and also use it as spice plant [6].

[7], stated that the result of the identification of bangun-bangun plants in three areas of West Sumatra shows almost the same morphological characteristics, this is due to the growing condition of the three places almost the same, but Padang Panjang is the most eligible to grow this plant. This can be seen from environmental conditions, plant height $(50-100 \mathrm{~cm})$, number of branches per plant (9-24 pieces), leaf length $(5-8 \mathrm{~cm})$, leaf width $(5-8 \mathrm{~cm})$, long petiole ( 4-7 $\mathrm{cm})$ and number of leaves per plant (97-206 pieces).

Bangun-bangun leaves are known to contain thymol active compounds that function as alternative antibiotics. Bangun-bangun leaves also contain carvacrol compounds known as antiinflammatory and anti-inflammatory compounds, $\alpha$-Terpinene and $\gamma$-Terpinene compounds that act as antioxidants. Overall the bangun-bangun leaves function as pharmaceutics compounds that function as buffers, anti-bacterial, antioxidants, lubricants, plasticizers, dyes, and stabilizers [8]. The use of natural food additives sourced from plant products that have functional benefits are increasingly developed among other medicinal plants that are widely available in Indonesia, especially West Sumatra. [9], giving 5\% of Simplicia bangun-bangun leaves in urea saka block 
can increase milk production as much as $10 \%$ in the group of the prosperous green valley of Padang Panjang.

in the framework of efforts to develop and utilize traditional medicinal plants one of which is a build bangun-bangun leaf developed Batak society that can maintain, improve the health of the body and increase milk production of breastfeeding mothers. Based on pharmaceutical components and nutrients from bangun-bangun leaves [8] then conducted a study aimed to see the effect of bangun-bangun leaves extract against the microbial population in the digestive tract and the performance of broiler.

\section{Materials And Methods}

This research consists of two stages of producing bangun-bangun leaves extract and applying to broiler livestock. To achieve the objectives of the research then it must be supported by materials, tools, and methods used in research.

\subsection{Materials and instruments}

Bangun-bangun leaves (Coleus amboinicus, L) originating from Padang Panjang, one-weekold broiler, starter phase feed (code 311) and feed mixture consisting of corn, fish meal, soybean meal, bran, oil and premix) chemical for phytochemical analysis of bangun-bangun leaves extract.

The instruments used in this study were analytical scales, trophies, measuring cups, petri dishes, 2.5-liter glass bottles, vacuum pumps, one-set distillation equipment, refrigerators, oneset evaporators, ovens, spectrophotometers, blenders, stirrer glass pipes. Cage metabolic wire, feed and drink place, scales, plastic container, analysis kjeidahl, crude fiber analysis, vacuum pump, furnace, magnetic stires, bomb calorimeter, refrigerator, oven, incubator, autoclave, spectrophotometer, distillation, broiler production cage.

\section{$2.2 \quad$ Research Design}

This research was designed by Completely Random Design with 8 treatments and 4 replication. A significant difference was determined Duncan's Multiple Range Test at 5\%.

This study was conducted based on 8 treatment bangun-bangun leaves extract addition which consists of :

D1 $=$ Without the addition of antibiotics (control)

D2 $=$ The addition of commercial antibiotics in the diet

D3 $=$ Feed with the addition of additive feed (dry Simplicia $20 \mathrm{~g} / \mathrm{kg}$ in ration)

D4 $=$ Feed with the addition of feed additive (dry Simplicia $40 \mathrm{~g} / \mathrm{kg}$ in ration)

D5 $=$ Feed with the addition of feed additive (extraction with ethanol $2 \mathrm{~g} / \mathrm{kg}$ deep rations)

D6 $=$ Feed with the addition of feed additive (extraction with ethanol $4 \mathrm{~g} / \mathrm{kg}$ in ration

D7 $=$ Feed with the addition of feed additive (extraction with water $2 \mathrm{~g} / \mathrm{kg}$ in ration)

D8 $=$ Feed with the addition of feed additive (extraction with water $4 \mathrm{~g} / \mathrm{kg}$ in ration)

Examination population of bacteria an aerob:

1. Chickens that have been cut and cleaned from the feathers, then taken the chicken's small intestine and pour the contents into sterile baker glass.

2. Homogenize the contents of the small intestine

3. Make retailer 1: 10 by $11 \mathrm{ml}$ insert into $99 \mathrm{ml}$ sterile BPW solution, then homogenize (shake 25 times). 
4. Next pipette $1 \mathrm{ml}$ from the retailer, put it into $9 \mathrm{ml}$ retailer to 1: 100 dilution. This dilution is continued until the desired solution depends on the content of the bacteria tested.

5. Pipette as much as $1 \mathrm{ml}$ of each dilution and insert it into a sterile the cup Petrides that have been labeled earlier according to its dilution.

6. Pour the warm liquid (40-50) into each of the cup Petrides. Then wiggle carefully the cup like the number eight and let it solidify.

7. After order solidifies, put the cup Petrides into an incubator with temperature $37^{\circ} \mathrm{C}$ for 24 - 36 hours.

8. Calculate the visible colonies of each dilution.

\subsection{Escherichia coli examination}

1. $25 \mathrm{~g}$ of intestine contents, insert into sterile plastic and add 225 peptone water buffer (BPW) $0.1 \%$ BPW and shaken in a stomacher for 2 minutes. This solution as diluent $10^{1}$.

2. Create serial dilutions $\left(10^{1}, 10^{2}, 10^{3}, 10^{4}\right)$ by taking $1 \mathrm{ml}$ of the present solution, then entering into $9 \mathrm{ml}$ of BPW solution, then the concentration of $10^{3}$ thus follows.

3. The prepared solution is then inoculated on VRB or VRBD overlay and incubation at a temperature of $35-37^{\circ} \mathrm{C}$ for $24-48$ hours.

4. Inoculation results in bacteria Escherichia coli.

5. Calculating E. coli is done by counting the number of colonies that are red.

Table 1. Chemical composition of waking leaves (Coleus amboinicus, $L$ )

\begin{tabular}{ll}
\hline $\begin{array}{l}\text { Chemical } \\
\text { composition }\end{array}$ & \multicolumn{2}{c}{ Bangun-bangun } & leaves \\
\hline Water content & 15.44 \\
\hline Dry matter & 84.56 \\
\hline Crude protein & 19.24 \\
\hline Rough fat & 4.21 \\
\hline Crude fiber & 9.08 \\
\hline Ash & 11.34 \\
\hline $\mathrm{Ca}$ & 2.133 \\
\hline $\mathrm{P}$ & 0.312 \\
\hline $\mathrm{GE}(\mathrm{Kkal} / \mathrm{g})$ & 4070.51 \\
\hline
\end{tabular}

The rations used were self-stirred rations with a protein content of $21.5 \%-22 \%$ with an energy content of about $3000 \mathrm{Kcal} / \mathrm{kg}$. The ingredients of the ration are corn, fish meal, fine bran, soybean meal, mineral, oil, and antibiotic commercial).

Table 2. Composition and nutrient content of the ration based on the calculation

\begin{tabular}{lllllllll}
\hline Food material & A & B & C & D & E & F & G & H \\
\hline Corn & 58 & 58 & 56,5 & 56,5 & 57,8 & 57,6 & 57,8 & 57,8 \\
\hline Rice bran & 8 & 8 & 8 & 6 & 8 & 8 & 8 & 8 \\
\hline Soybean meal & 22 & 22 & 21,5 & 21,5 & 22 & 22 & 22 & 22 \\
\hline
\end{tabular}




\begin{tabular}{lllllllll}
\hline Fish flour & 9 & 9 & 9 & 9 & 9 & 9 & 9 & 9 \\
\hline Oil & 2 & 2 & 2 & 2 & 2 & 2 & 2 & 2 \\
\hline Mineral & 1 & 1 & 1 & 1 & 1 & 1 & 1 & 1 \\
\hline Simplicia & - & - & 2 & 4 & - & - & - & - \\
\hline Water extract & - & - & - & - & - & - & 0,2 & 0,4 \\
\hline Ethanol extract & - & - & - & - & 0,2 & 0,4 & - & - \\
\hline Colamox & - & - & - & - & - & - & - & - \\
\hline Total & 100 & 100 & 100 & 100 & 100 & 100 & 100 & 100 \\
\hline Content of Nutrient Rations Based on Calculations & & & & & \\
\hline Crude protein & 22,03 & 22,08 & 22,03 & 22,18 & 21,38 & 22,09 & 21,38 & 22,09 \\
\hline Crude fiber & 3,54 & 3,54 & 3,68 & 3,45 & 3,54 & 4,09 & 3,54 & 4,09 \\
\hline Fat & 4,09 & 4,09 & 4,07 & 4,03 & 4,09 & 4,09 & 4,09 & 4,09 \\
\hline Ca & 1,29 & 1,29 & 1,32 & 1,35 & 1,28 & 1,29 & 1,28 & 1,29 \\
\hline P & 0,81 & 0,80 & 0,79 & 0,77 & 0,80 & 0,8 & 0,80 & 0,80 \\
\hline Metabolic energy & 3014,5 & 3014,5 & 3016,6 & 3073,6 & 3014,5 & 3007,8 & 3014,5 & 3007,8 \\
\hline Description: based on lab analysis. agricultural polytechnic Payakumbuh country, (2017) and \\
calculations in the preparation of rations
\end{tabular}

The rations used were self-stirred rations with a protein content of $21.5 \%-22 \%$ with an energy content of about $3000 \mathrm{Kcal} / \mathrm{kg}$. The ingredients of the ration are corn, fish meal, fine bran, soybean meal, mineral, oil, and Colamox).

\subsection{Data analysis}

The results will be analyzed by ANOVA and if significantly different will be tested further with Duncan's Multiple Range Test. Each treatment consisted of 32 experimental cage units, each experimental unit consisting of 5 chickens.

\section{Result And Discussion}

To achieve the purpose of the application of bangun-bangun leaves extract that serves as feed additive then the required data as parameters is to calculate the population of Escherichia coli bacteria in the digestive tract, bacterial population, the increase of broiler body weight, ration consumption and ration conversion.

\subsection{The population of Escherichia coli bacteria in the small intestine}

The treatment method of bangun-bangun leaves extraction in ration had a significant effect $(\mathrm{P}<0,05)$ to a population of E. coli bacteria. The average population of Escherichia coli bacteria in the small intestine during the study was $0.13 \times 106-1.48 \times 10^{6}$.

Based on the result of the population variance of $E$. coli real bacteria $(\mathrm{P}<0,05)$ influenced by the extraction method of bangun-bangun leaves. Duncan Multiple Range Test results were extracted with $96 \%$ ethanol solvent with $0.4 \%$ in ration showed the lowest E. coli population of $0.13 \times 10^{6}$ and the highest E. coli population was $4 \%$ simplicia in rations of $1,48 \times 10^{6}$. 
Giving $0.4 \%$ ethanol extract $96 \%$ (E) in the ration was not significantly different $(\mathrm{P}>0.05)$ with $2 \%$ Simplicia (C) in the ration. Treatment $0.4 \%$ ethanol extract (E), Simplicia $2 \%(\mathrm{C})$, as antibacterial agent E. coli in broiler ration had significantly less E. coli bacteria $(\mathrm{P}<0.05)$ than positive control treatment (antibiotic colamoc), without antibiotics, $4 \%$ Simplicia, $0.2 \%$ ethanol extract, $0.2 \%$ water extract and $0.4 \%$ water extract in the ration. $0.2 \%$ water extract, $0.4 \%$ in the ration and $0.2 \%$ of wilted leaf ethanol extract have not been able to inhibit the growth of $E$. coli bacteria so that the population is more than $0.4 \%$ of bangun-bangun leaves ethanol extract. This may be due to the concentration of active compounds present in the bangun-bangun leaves yet sufficient to inhibit the growth of $E$.coli in the gastrointestinal tract.

The low population of $E$. coli in the small intestine of broiler which got $2 \%$ simplicia ration and $0.4 \%$ ethanol extract showed that the active compound bangun-bangun leaves can inhibit the growth of $E$. coli bacteria in the digestive tract. Bangun-bangun leaves have antibacterial compounds such as essential oils [10], triterpenoids, saponins [11], flavonoids [10]-[12] and tannin [12].

\subsection{Population Bacteria An aerob in the Small Intestine.}

The treatment of the extraction method of bangun-bangun leaves in the ration had a significant effect $(\mathrm{P}<0,05)$ on aerobic bacteria population. The average population of bacteria an aerob in the small intestine during the study was $1.5 \times 10^{6}-4.9 \times \mathbf{1 0}^{7}$.

Based on the result of the actual population aerobic bacteria population $(\mathrm{P}<0,05)$ influenced by extraction method of bangun-bangun leaf. Duncan Multiple Range Test results were extracted with $96 \%$ ethanol solvent with $0.4 \%$ in ration giving the lowest aerobic bacteria population of $1.5 \times 10^{6}$ and the highest aerobic bacteria population was $0.2 \%$ water extract in $(\mathrm{P}$ $<0.05$ ) with positive control (A), negative control (B), simplicia $2 \%$ (C) in a significantly different ration $(\mathrm{P}<0,05)$, simplicia $4 \%(\mathrm{D})$, ethanol extract $0,2 \%(\mathrm{E})$, water extract $0,2 \%(\mathrm{G})$ and water extract $0,4 \%(\mathrm{H})$ in ration.

Table 3. Average number of Escherichia coli bacteria, anaerobic bacteria

\begin{tabular}{clc}
\hline nt & $\begin{array}{l}\text { Bacterial } \\
\text { population E. coli }\end{array}$ & $\begin{array}{l}\text { Bacterial } \\
\text { population } \\
\text { aerobic }\end{array}$ \\
\hline $\mathrm{A}$ & $1,16 \times 10^{6 \mathrm{ab}}$ & $1,88 \times 10^{7 \mathrm{~b}}$ \\
$\mathrm{~B}$ & $1,14 \times 10^{6 \mathrm{ab}}$ & $1,41 \times 10^{7 \mathrm{~b}}$ \\
$\mathrm{C}$ & $0,2 \times 10^{6 \mathrm{c}}$ & $1,87 \times 10^{6 \mathrm{~b}}$ \\
$\mathrm{D}$ & $1,48 \times 10^{6 \mathrm{a}}$ & $1,14 \times 10^{7 \mathrm{~b}}$ \\
$\mathrm{E}$ & $1,15 \times 10^{6 \mathrm{ab}}$ & $9,67 \times 10^{6 \mathrm{~b}}$ \\
$\mathrm{E}$ & $0,13 \times 10^{6 \mathrm{c}}$ & $1,5 \times 10^{6 \mathrm{a}}$ \\
$\mathrm{G}$ & $1,19 \times 10^{6 \mathrm{ab}}$ & $4,9 \times 10^{7 \mathrm{~b}}$ \\
$\mathrm{H}$ & $0,9 \times 10^{6 \mathrm{~b}}$ & $3,22 \times 10^{7 \mathrm{~b}}$ \\
\hline
\end{tabular}

Inf. different letters on the same lane showed significant differences $(\mathrm{P}<0.05)$

\subsection{Weight gain}

The mean body weight gain during the study ranged from $570.98-724.0 \mathrm{~g} /$ tail was listed in Table 4. The results of the variance showed that the bangun-bangun leaves extract with different extract methods in the ration had no significant effect $(\mathrm{P}>0.05)$ to the increase of broiler body weight. The number of body weight gain containing $0.4 \%$ water extract is higher than other treatment that is $724 \mathrm{~g}$. 
The average of broilers' weight gain during four weeks of treatment was not significantly different $(\mathrm{P}>0.05)$ by different extraction methods to $0.4 \%$ level of bangun-bangun leaves extract in the diet. Different weight gain values were not significant $(\mathrm{P}>0.05)$ to $0.4 \%$ bangunbangun leaves extract meant that bangun-bangun leaves extracts up to that level did not have a significant effect on weight gain. This is suspected because the levels of active compounds in the extract and Simplicia have not been able to support the mechanism to increase the chicken body weight increase. The content of waking leaves active substances resulting from this study are triterpenoids, saponins, flavonoids and tannins that decrease the population of E. coli in the intestinal tract. Furthermore [13], reported that active substances, triterpenoids, saponins, flavonoids, and tannins can decrease $E$. coli populations so that smooth muscle contraction decreases and digestive tract surface crackability can be avoided. Decreased contraction of intestinal smooth muscle and prevention of surface damage of the digestive tract cause the absorption of food substances to be more perfect. This will affect the process of meat formation and acceleration of broiler growth, but the results of this study have not supported until the acceleration of growth.

The weight gain was not significantly different $(\mathrm{P}>0.05)$, closely related to the number of rations consumed during the study. During the chicken, study consumed relatively the same ration, because of iso protein and iso calories, besides that broiler health almost the same between treatment and normal body condition. Consumption of broiler ration is related to the inclusion of some nutrient elements into the chicken body, the higher the amount of ration consumption will increase the body weight will be increased, otherwise if the value of ration consumption is low then the increase of body weight generated will decrease.

One that sustains growth is feeding additives. According to Widodo [14], feed additive can help the process of digestion and absorption of food nutrition. The mechanism of action is to kill pathogenic microorganisms in the gastrointestinal tract, thus killing the microorganism and its crust attached to the intestine. This condition results in the intestinal wall become thinner so that the absorption of nutrients becomes increased.

In addition, to feed consumption factors, the presence of terpenoid compounds also affects the increase in chicken weight. The results showed that the active compound components of ethanol extract and leaf water bangun-bangun allegedly experienced evaporation during storage. According Lenny[15], during the storage process, terpenoid compounds contained in the extract easily evaporate, so that the digestion becomes not optimal. The process of extract storage resulted in a volatile terpenoid component, so the process of digestion of food substance is not helpful in the process of enzyme secretion of amylase, lipase, and trypsin. Due to the low activity of the enzyme's impact on the digestibility of feed rations between the treatment and control to below, resulting in an increase in body weight is not significant. The activity of enzyme lipase, trypsin and amylase are very influential to the digestion process and absorption of food substance in the animal body [16]. The growth process will not run optimally if the activity of digestive enzymes does not work optimally.

The increase of body weight of the study on the treatment of Table $4(658-724 \mathrm{~g} /$ head / 4 weeks), this value is slightly lower than the results of research [2], using feed additive bay leaves (Syzygium polyanthum) as antibacterial in rations which has a component of active substances such as bangun-bangun leaves that is equal to $965-1003 \mathrm{~g} /$ head / five weeks. It is predicted from the difference in the amount and form of leaf extract given to the broiler.

Table 4. Average ration consumption, body weight gain and conversion rations 


\begin{tabular}{lllll}
\hline Treatment & $\begin{array}{l}\text { Consumption of } \\
\text { ration } \\
\text { during study }\end{array}$ & $\begin{array}{l}\text { Body } \\
\text { gain } \\
\text { during study }\end{array}$ & $\begin{array}{l}\text { weight } \\
\text { (g/tail) }\end{array}$ & FCR \\
\hline A & 1583.18 & 570.98 & 2.78 \\
B & 1429.44 & 620.63 & 2.32 \\
C & 1402.75 & 658.63 & 2.20 \\
D & 1650.00 & 627.23 & 2.77 \\
E & 1424.38 & 624.00 & 2.15 \\
F & 1372.90 & 653.75 & 2.11 \\
G & 1515.25 & 669.00 & 2.27 \\
H & 1416.75 & 724.00 & 2.08 \\
\hline
\end{tabular}

\subsection{Consumption of Rations}

The consumption of ration that was not significantly different $(\mathrm{P}>0.05)$ showed that up to $4 \%$ of simplicia, $0.4 \%$ ethanol extract and water extract in the ration had no effect on broiler consumption. The same body condition between the treated chickens that get the simplicia, ethanol extract and water extracts cause the consumption of ration relatively the same. Broiler body condition is closely related to the consumption of broiler rations, so that impact on the performance of livestock itself [14].

The consumption of ration that was not significantly different $(\mathrm{P}>0.05)$ on the suspected treatment was secondary metabolite of bangun-bangun leaves (Coleus ambinicus, L) example alkaloids, flavonoids, terpenoids and saponins that can evaporate during storage. According to Lenny[15], states that in the extract contained secondary metabolite compounds, which in the storage process tend not to be in stable condition. During storage of 3 weeks, the secondary metabolite compound is predominantly terpenoid, in which time it is volatile. So the aromatic nature in terpenoids contained in the extract tends to decrease. The function of the aromatic compounds contained in the extract is to stimulate the consumption of the ration by stimulating the aroma in it

The digestive process can be assisted by terpenoid compounds, by stimulating the nervous system of excretion, so that it can release the gastric juice enzyme amylase, lipase, trypsin, and pepsin are excreted into the stomach and intestines. The resulting enzyme may serve as a catalyst in the process of hydrolysis of dextrin, starch, and glycogen to maltose. In addition, these enzymes also serve as fat breakers, proteins, and peptone [17]. The tendency of low hunger properties arises due to the digestion of fat and starch run optimally which affects the consumption of rations. The effect is the relative consumption of the same ration between control and treatment of chickens.

The consumption of research ration at $1372-1650 \mathrm{~g} /$ head / 4 weeks maintenance treatment was lower when compared to the results of reference [18] research, which used the leaves of laurel (Syzygium polyanthum) in a ration that had active substance components such as bangunbangun leaves, ie by $2077-2163 \mathrm{~g} /$ head / five weeks of maintenance. This is suspected because there is a different treatment of the leaves that cause the active ingredients to also experience differences.

\subsection{Conversion rations}

The average conversion of rations during the study as listed in Table 4. Conversion of ration given ethanol extract and water extract was lower than control. With increasing levels of the good administration of the ethanol extract, water extracts then the ration conversion decreases. 
The result of variance analysis showed that there was no significant difference $(\mathrm{P}>0,05)$ between the extraction method with different levels in decreasing ration conversion.

The average conversion control ration control (colamox antibiotic) was 2.77 , while the mean conversion rate of $0.2 \%$ and $0.4 \%$ of the ethanol extract in the rations were 2.15 and 2.11 respectively. Mean conversion rates of $0.2 \%$ and $0.4 \%$ of aqueous extracts were 2.27 and 2.08, respectively. While the conversion of rations given simplicia with the level of $2 \%$ and $4 \%$ in the rations in the sequence is 2.22 and 2.77 .

The conversion value of ration that was not significantly different $(\mathrm{P}>0.05)$ between treatments was due to the association between feed intake (Table 4) and weight gain (Table 4) which did not differ significantly to the $0.4 \%$ level of wilted leaf extract. This is in accordance with the opinion of [16], that the increase of poultry body weight resulting from the number of rations consumed in a certain period will affect the value of the conversion of the ration. The lower the feed conversion values obtained, the better.

Equal health conditions of the livestock cause the consumption of rations among the samen treatment, resulting in relatively equal livestock growth. Rations consumed by livestock will be used for the formation of cells and tissues. These cells and tissues are the basic substances for the growth of livestock [19]. Provision of bangun-bangun leaves extract either in the form of simplicia, ethanol extract and water extract in ration with different levels did not affect the conversion of rations (Table 4). This is due to the presence of antibacterial compounds in bangun-bangun leaves that are able to inhibit the growth of harmful bacteria, thus giving the same effect with the treatment of antibiotics and control treatment of ration conversion. This shows that giving bangun-bangun leaf extracts with ethanol and water solvents up to $0.4 \%$ and $4 \%$ simplicity in the ration does not cause a negative effect on the efficiency of ration use. The negative effects of tannins in extracts and leaf-build simplicia, which can bind feed proteins, minerals and digestive enzymes [20] [21], which can inhibit the digestive process of feed, are not seen in this study.

The conversion of research ration at treatment $2.08-2.77$ for four maintenance values was similar to that of reference [2], which used Syzygium polyanthum flour in a ration that had an active substance component such as leaf bangun-bangun, ie $2.07-2.17$ for five weeks of maintenance. This is suspected because there is a different treatment of the leaves that cause the active ingredients to also experience differences.

\section{Conclusions}

Based on the research results can be concluded Giving bangun-bangun leaves with different extract methods affect the population of bacteria Escherichia coli and population an aerob. Giving bangun-bangun leaves with different extract methods have no significant effect on weight gain, ration consumption and ration conversion. Provision of water extract and ethanol extract as much as $0.4 \%$ in the ration can still be tolerated broiler. Giving simplicia to $4 \%$ in ration can still be tolerated broiler.

\section{References}

[1] U. Santoso, "Pengaruh penambahan ekstrak daun katuk terhadap kualitas telur dan berat organ dalam," J. Sain Peternak. Indones., vol. 2, no. 1, pp. 5-10, 2007.

[2] K. G. Wiryawan, S. Luvianti, W. Hermana, and S. Suharti, "Peningkatan Performa Ayam Broiler dengan Suplementasi Daun Salam [Syzygium polyanthum (Wight) Walp] Sebagai Antibakteri Escherichia coli," Media Peternak., vol. 30, no. 1, 2007. 
[3] A. Sudarman and H. Solikhah, "Performance and meat cholesterol content of broiler chickens fed Pluchea indica L. leaf meal reared under stress condition," Media Peternak., vol. 34, no. 1, p. 64, 2011.

[4] W. Selawa, M. R. J. Runtuwene, and G. Citraningtyas, "Kandungan flavonoid dan kapasitas antioksidan total ekstrak etanol daun binahong [anredera cordifolia (ten.) steenis.]," Pharmacon, vol. 2, no. 1, 2013.

[5] K. Heyne, Useful plants of Indonesia. Jakarta: Yayasan Sarana Wana Jaya, 1987.

[6] BPPT (Agency for Assessment \& Application of Technology), Cumin (Coleus amboinicus). Jakarta: Science and Technology horizon, 2002.

[7] \& Y. S. Siregar, R., N. Fati, S. Wahono, Characterization of Bangun-bangun Leaves (Coleus amboinicus L.) West Sumatera area. West Sumatera, 2013.

[8] M. Lawrence and D. R. Naiyana, Modified Nutraceutical Composition. Melbourne: Freehills patent and Trademark Attorneys, 2005.

[9] N. Fati, I. Irda, and D. Syukriani, "Using of Bangun-Bangun Leafs (Coleus Amboinicus, L) on Red Sugar Block to Upgrading Milk Production of Frisian Holstein," Int. J. Adv. Sci. Eng. Inf. Technol., vol. 4, no. 2, pp. 84-86, 2014.

[10] A. Samosir, "Effect of extra wilted leaves ethanol (Plectranthus amboinicus (L) Spreng) on the inhibition of carcinogenic mammae of benzo female induced benzo $(\alpha)$ pyrene," University of North Sumatra, 2014.

[11] C. I. Dalimunthe, Y. R. V. Sembiring, T. M. Andriyanto, HD. Siregar, H. S. Darwis, and D. A. Barus, Identification and test of secondary metabolites bangun-bangun (Coleus amboinicus) against white root disease (Rigidoporus microporus), in the laboratory. Indonesian, 2016.

[12] F. Tafzi, "Identification and mechanism of the bioactive components of tomato leaf extract (Plectranthus amboinicus, L) Spreng) as antioxidants and lactation function in epithelial cells of human milk gland in invitro," IPB, 2016.

[13] C. P. Setiawan, "Effect of chemical and physical treatment on antimicrobial activity of bay leaf (Syzygium polyanthum (Wight) Walp)," Bogor Agricultural University, 2002.

[14] W. Widodo, "Contextual Nutrition and Feeding. Higher Education Research Education Department project," Muhamadiyah University, 2002.

[15] S. Lenny, "Terenoids and steroids. Scientific work," University of North Sumatra, 2006.

[16] L. \& N. Purwaningsih, "Basic livestock nutrition," University of Lampung, 2002.

[17] \& R. W. Habibah, A. S., Abun, "Influence of jengkol skin extract (Pithecellobium juringa (Jeck) Pain in rations on broiler performance broiler," Universitas Padjajaran, 2012.

[18] K. Nova, T. Kurtini, and Riyanti, "Business management textbook poultry," University of Lampung, 2002.

[19] \& M. H. Hasiib, E. T., Riyanti, "Effect of binahong leaf extract (Anredera cordifolia (Ten.) Steenis) in drinking water on broiler performance," Integr. Anim. Husb. Journals, vol. 3, 2015.

[20] K. G. Wiryawan and B. Tangendjaja, "Tannin degrading bacteria from Indonesian ruminants," in ACIAR PROCEEDINGS, 1999, pp. 123-126.

[21] A. Cannas, "Tannins: fascinating but sometimes dangerous molecules," Cornell Cals, 2001 [Online]. Available: http://poisonousplants.ansci.cornell.edu/toxicagents/tannin.html. 